\title{
Rhizobium yanglingense sp. nov., isolated from arid and semi-arid regions in China
}

\footnotetext{
1 Department of Microbiology, College of Biological Sciences, China Agricultural University, Beijing 100094, PR China

2 Max-Planck-Institute for Terrestrial Microbiology, Group Symbiosis Research, Karl-von-Frisch-Str., D-35043 Marburg, Germany

3 Laboratorio de Microbiología Agrícola, Escuela Nacional de Ciencias Biologicas, Instituto Politecnico Nacional, Ap. P. 63-246, 02800 México D. F., Mexico
}

\author{
Zhi Yuan Tan, ${ }^{1,2}$ Feng Ling Kan, ${ }^{1}$ Gui Xiang Peng, ${ }^{1}$ En Tao Wang, ${ }^{1,3}$ \\ Barbara Reinhold-Hurek ${ }^{2}$ and Wen Xin Chen ${ }^{1}$
}

Author for correspondence: Wen Xin Chen. Tel: +86 10 62891854. Fax: +86 1062891055. e-mail: wenxin_chen@263.net

\begin{abstract}
A novel rhizobial group, cluster 9, defined in previous research [Tan, Z. Y., Wang, E. T., Peng, G. X., Zhu, M. E., Martínez-Romero, E. \& Chen, W. X. (1999). Int $J$ Syst Bacteriol 49, 1457-1469], was further characterized by determination of DNA base composition, whole-cell protein SDS-PAGE analysis, DNA-DNA hybridization, 16S rRNA gene sequencing and host specificity. These isolates were collected from the wild legumes Amphicarpaea trisperma, Coronilla varia and Gueldenstaedtia multiflora growing in arid and semi-arid regions in northwestern China. Isolates within cluster 9 grouped into a single cluster above a similarity level of $\mathbf{9 0 . 6} \%$ in a cluster analysis based on protein SDS-PAGE, and they were differentiated from defined rhizobial species. Comparative analysis of $16 \mathrm{~S}$ rRNA gene sequences showed that isolate CCBAU $71623^{\top}$, representing cluster 9, was most related to Rhizobium gallicum and Rhizobium mongolense. The DNA-DNA homologies were lower than $42 \cdot 4 \%$ among cluster 9 and defined species, including $R$. gallicum and $R$. mongolense. These data indicated that cluster 9 was a unique genomic species. Isolates within this cluster could share their host plants. They could not nodulate Galega orientalis and Leucaena leucocephala and formed ineffective nodules on Phaseolus vulgaris. This group could also be differentiated from defined species by phenotypic characteristics. It is therefore proposed as a new species, Rhizobium yanglingense, with isolate CCBAU 71623 as the type strain.
\end{abstract}

Keywords: Rhizobium yanglingense, Amphicarpaea trisperma, Coronilla varia, Gueldenstaedtia multiflora, phylogeny

\section{INTRODUCTION}

The description of new taxa of root- and stem-nodule bacteria has been accelerated by using a polyphasic approach (Vandamme et al., 1996) to characterize new isolates from various leguminous plants. Among the 36 defined species within the genera Azorhizobium, Bradyrhizobium, Mesorhizobium, Rhizobium and Sinorhizobium, seven species, including Rhizobium mongolense (van Berkum et al., 1998), Rhizobium huautlense (Wang et al., 1998), Mesorhizobium plurifarium (de Lajudie et al., 1998b), Mesorhizobium amorphae (Wang et al., 1999a), Rhizobium undicola (de Lajudie et

Abbreviation: UPGMA, unweighted pair group method with arithmetic averages.

The GenBank accession numbers for the $16 \mathrm{~S}$ rRNA sequences of strains CCBAU 71462 and CCBAU $71623^{\top}$ are AF195031 and AF003375, respectively. al., 1998a), Sinorhizobium arboris and Sinorhizobium kostiense (Nick et al., 1999), have been described in the last 3 years. The characterization of new isolates and the subsequent description of new taxa have improved our knowledge about the diversity of rhizobia and have offered a better view of the phylogenetic relationships and the evolution of these bacteria. Reviews of the taxonomy and phylogeny of rhizobia have been published by van Berkum \& Eardly (1998) and Wang \& Martínez-Romero (2000).

In addition, new data on rhizobial diversity are accumulating rapidly; for example, the diverse rhizobial populations associated with Leucaena leucocephala have been classified into 12 rDNA types, including Mesorhizobium, Rhizobium and Sinorhizobium (Wang et al., 1999b). Some novel lineages have been revealed by characterization of various Bradyrhizobium populations associated with different 
Table 1. Strains and isolates used in this research

\begin{tabular}{|c|c|c|}
\hline Strain* & Name of host & Origin $\uparrow$ \\
\hline \multicolumn{3}{|l|}{ Cluster 9 (R. yanglingense) } \\
\hline CCBAU 71462 (SH 2462) & Coronilla varia & Gansu \\
\hline CCBAU 71012 (SH 246012) & Coronilla varia & Gansu \\
\hline CCBAU 71113 (SH 17113) & Coronilla varia & Shaanxi \\
\hline CCBAU 71718 (SH 1718) & Coronilla varia & Shaanxi \\
\hline CCBAU $71623^{\mathrm{T}}\left(\mathrm{SH} 22623^{\mathrm{T}}\right)$ & Gueldenstaedtia multiflora & Gansu \\
\hline CCBAU 71465 (SH 1456) & Amphicarpaea trisperma & Shaanxi \\
\hline CCBAU 71121 (SH 27121) & Amphicarpaea trisperma & Gansu \\
\hline CCBAU 71931 (SH 28931) & Amphicarpaea trisperma & Gansu \\
\hline CCBAU 71975 (SH 0975) & Amphicarpaea trisperma & Gansu \\
\hline \multicolumn{3}{|l|}{ New isolates } \\
\hline CCBAU 71414 (SH 414) & Coronilla varia & Shaanxi \\
\hline CCBAU 71423 (SH 423) & Gueldenstaedtia multiflora & Shaanxi \\
\hline CCBAU 71445 (SH 445) & Coronilla varia & Shaanxi \\
\hline \multicolumn{3}{|l|}{ Reference strains } \\
\hline R. leguminosarum USDA $2370^{\mathrm{T}}$ & bv. viceae & United States \\
\hline R. tropici CIAT $899^{\mathrm{T}}$ & Phaseolus vulgaris & Columbia \\
\hline R. tropici A CFN 299 & Phaseolus vulgaris & Brazil \\
\hline R. mongolense USDA $1844^{\mathrm{T}}$ & Meliloti luthenica & Inner Mongolia \\
\hline R. galegae HAMBI $540^{\mathrm{T}}$ & Galega orientalis & Finland \\
\hline R. hainanense $\mathrm{I}^{6} 6^{\mathrm{T}}$ & Desmodium smuatum & Hainan \\
\hline R. gallicum USDA $2918^{\mathrm{T}}$ & Phaseolus vulgaris & France \\
\hline R. gallicum FL27 & Phaseolus vulgaris & Mexico \\
\hline R. giardinii $\mathrm{H} 152^{\mathrm{T}}$ & Phaseolus vulgaris & France \\
\hline
\end{tabular}

* CCBAU, Culture Collection of Beijing Agricultural University, China; USDA, Beltsville Rhizobium Culture Collection, Beltsville Agricultural Research Center, Beltsville, MD, USA; CIAT, Rhizobium Collection, Centro International de Agricultura Tropical, Cali, Columbia; CFN, Centro de Investigatción sobre Fijación de nitrógeno, Universidad Nacional Autonoma de Mexico, Cuernavaca, Mexico; HAMBI, Culture Collection of the Department of Microbiology, University of Helsinki, Helsinki, Finland.

$\uparrow$ Gansu, Shaanxi, Inner Mongolia and Hainan, provinces of China.

hosts (Barrera et al., 1997; Dupuy et al., 1994; Lafay \& Burdon, 1998; van Rossum et al., 1995). All these data indicate the existence of unknown rhizobia in nature and new taxa are expected when further investigation is performed on novel isolates or groups.

In our previous study, novel groups, clusters 9, 14 and 15 , were found in rhizobial isolates from the wild legumes Caragana prurinosa, Caragana microphylla, Caragana intermedia, Amorpha fruticosa, Sophora viciifolia, Coronilla varia, Amphicarpaea trisperma, Glycyrrhiza uralensis and Gueldenstaedtia multiflora growing in the arid and semi-arid regions in the northwestern areas of China. They were identified as Rhizobium and Mesorhizobium by their phenotypic features and by comparative RFLP analysis of PCRamplified 16S rRNA genes (Tan et al., 1999). In the present research, new isolates belonging to cluster 9 were obtained from host plants Coronilla varia and Gueldenstaedtia multiflora. These new isolates, together with those used in the previous study (Tan et al., 1999), were further characterized. The object was to clarify the taxonomic position of cluster 9 .

\section{METHODS}

Strains and isolates. All strains and isolates used in this research are listed in Table 1. Three new isolates were obtained from the root nodules of Coronilla varia, Amphicarpaea trisperma and Gueldenstaedtia multiflora growing in the fields of arid and semi-arid regions where the cluster 9 isolates were found (Tan et al., 1999). All bacteria were subcultured in YMA medium (Vincent, 1970) and maintained in $20 \%$ glycerol solution at $-20{ }^{\circ} \mathrm{C}$.

SDS-PAGE of whole-cell proteins. The medium and procedures described previously (Reinhold-Hurek et al., 1993a, b) were used for growing the bacteria and for harvesting the cells. Fresh cells were weighed and suspended in extraction buffer (Laemmli, 1970) at a concentration of $150 \mathrm{mg} \mathrm{ml}^{-1}$. Procedures for extraction of whole-cell proteins and electrophoresis described by Kiredjan et al. (1986) and Schagger \& von Jagow (1987) were used. Two independent samples were prepared from strains CCBAU $71623^{\mathrm{T}}$ and CCBAU 71462 for checking reproducibility. Universal Software 1D Advanced from AABI was used for normalization of the protein profiles and numerical analysis using the unweighted pair group method with arithmetic averages (UPGMA; Sneath \& Sokal, 1973). A simple band match method was used for clustering. Bands with migration 
distances less than $3.0 \%$ different were defined as the same. The correlation coefficient is expressed as percentage similarity.

DNA base composition and DNA-DNA hybridization. DNAs were isolated and purified by the method described by Marmur (1961). DNA base composition was determined spectrophotometrically as described by De Ley (1970). DNA-DNA relatedness was determined by the initial renaturation rate method (De Ley et al., 1970) in $2 \times \mathrm{SSC}$ at $68^{\circ} \mathrm{C}$.

16S rRNA gene sequencing. Universal primers $25 f$ and $1492 \mathrm{r}$ (Lane, 1991) and the procedures of Hurek et al. (1997) were used for PCR amplification of the complete 16S rRNA gene from strain CCBAU 71462. A single strand of this PCR product was sequenced directly using the primers $35 \mathrm{fC}$, $342 \mathrm{fC}, 530 \mathrm{mfC}$ and $930 \mathrm{fC}$ and the procedures described by Hurek et al. (1997). Double-strand sequencing was performed for a cloned fragment of the PCR-amplified 16S rRNA gene from strain CCBAU $71623^{\mathrm{T}}$ as described previously (Chen et al., 1997; Tan et al., 1997). Alignment of the sequences obtained and related sequences from the GenBank database were performed using the RDP program (Maidak et al., 1999). The method of Jukes \& Cantor (1969) was used to calculate the distances among the aligned sequences. Tree topology was inferred by the neighbourjoining method (Saitou \& Nei, 1987), and the phylogenetic tree was constructed using the TREECON package (van de Peer $\&$ De Wachter, 1994). This package was also used to generate bootstrap confidence values (Felsenstein, 1985) from 100 replications of each sequence.

Cross-nodulation tests. Seeds of Gueldenstaedtia multiflora and Coronilla varia were scarified and seeds of Amphicarpaea trisperma were treated for 5 min with concentrated $\mathrm{H}_{2} \mathrm{SO}_{4}$. Standard procedures (Vincent, 1970) for surface sterilization, germination and inoculation of the seeds were used. The growth conditions of inoculated plants were described previously (Chen et al., 1995).

\section{RESULTS}

\section{SDS-PAGE of whole-cell proteins}

Three new isolates (CCBAU 71445, CCBAU 71414 and CCBAU 71423) and reference strains for cluster 9 and defined species were compared by SDS-PAGE of proteins. The three new isolates and four cluster 9 strains had similar electrophoretic patterns and they formed a group at a similarity level of $90 \%$ in a cluster analysis based upon the protein patterns (Fig. 1). The protein patterns of reference strains for related species were different from each other and from the cluster 9 strains. Different rhizobial species or groups were separated well below the similarity level of $90 \%$, with the exception of $R$. gallicum FL27 and $R$. giardinii, which had a similarity of $91 \%$ (Fig. 1).

\section{DNA base composition and DNA-DNA hybridization}

The $\mathrm{G}+\mathrm{C}$ content of new isolates CCBAU 71423, CCBAU 71414 and CCBAU 71445 was 60, 62 and $63 \mathrm{~mol} \%$, respectively, within the range of cluster 9 (59-63 mol \%) (Tan et al., 1999). The DNA relatedness among the reference strain CCBAU $71623^{\mathrm{T}}$ and the new isolates CCBAU 71423, CCBAU 71414 and

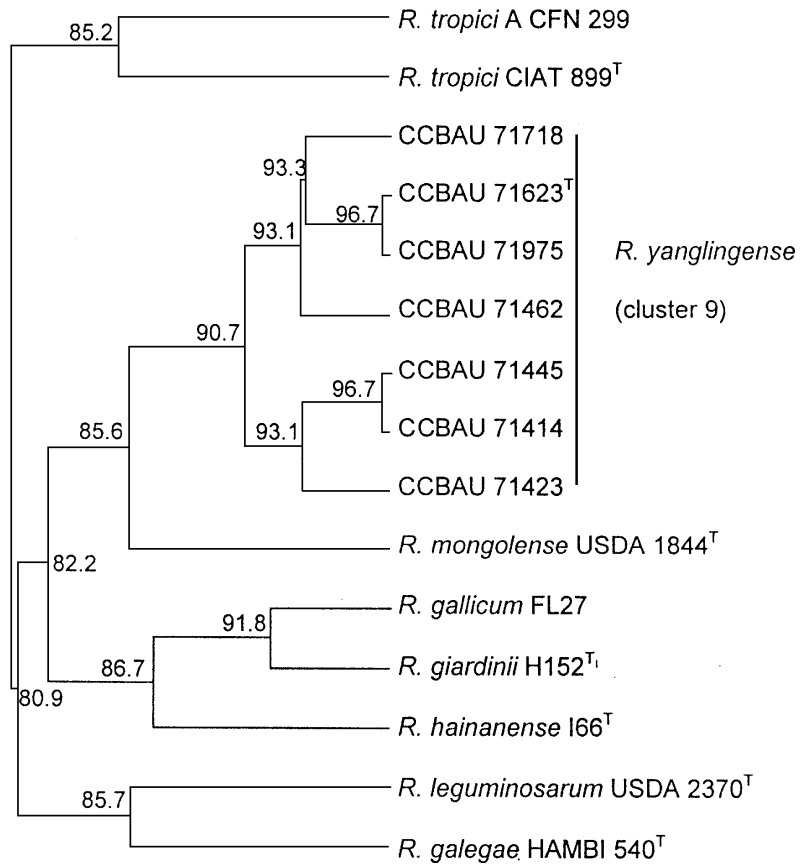

Fig. 1. Dendrogram showing the relationships of Rhizobium species derived from SDS-PAGE protein patterns by UPGMA clustering using simple band match. The numbers show the similarity levels of the band match.

CCBAU 71445 was $93 \cdot 5,90 \cdot 5$ and $86 \cdot 1 \%$, respectively, similar to those among other cluster 9 strains $(72 \cdot 3-$ $100 \%$ ) (Tan et al., 1999). The DNA relatedness among $R$. gallicum type strain USDA $2918^{\mathrm{T}}$ and the cluster 9 strains CCBAU $71623^{\mathrm{T}}$, CCBAU 71718, CCBAU 71113 and CCBAU 71012 was 37.9 (Tan et al., 1999), $13.9,42.4$ and $29.5 \%$, respectively, similar to those among strain CCBAU $71623^{\mathrm{T}}$ and type strains of related species $(<31 \%)$ (Tan et al., 1999).

\section{Sequence analysis of 16S rRNA gene}

Isolates CCBAU 71462 and CCBAU $71623^{\mathrm{T}}$ shared $99 \cdot 2 \% 16 \mathrm{~S}$ rRNA gene sequence similarity. Only the sequence of CCBAU $71623^{\mathrm{T}}$ was used for reconstruction of the phylogenetic tree (Fig. 2). In this tree, cluster 9 strains were grouped into the genus Rhizobium and most related to the sub-branch containing $R$. gallicum and $R$. mongolense. The sequence similarities were $99 \cdot 2 \%$ between cluster 9 and $R$. gallicum, and $99.0 \%$ between cluster 9 and $R$. mongolense. Similarity levels among cluster 9 and defined Rhizobium species were $96 \cdot 0-99 \cdot 2 \%$. Cluster 9 strains and other root- or stem-nodule bacteria shared 89.2-97.0\% $16 \mathrm{~S}$ rRNA gene sequence similarity.

\section{Cross-nodulation}

Cross-nodulation of strains or isolates within cluster 9 was checked. Isolates from Amphicarpaea trisperma, Coronilla varia and Gueldenstaedtia multiflora could share their host plants. None of the isolates within 


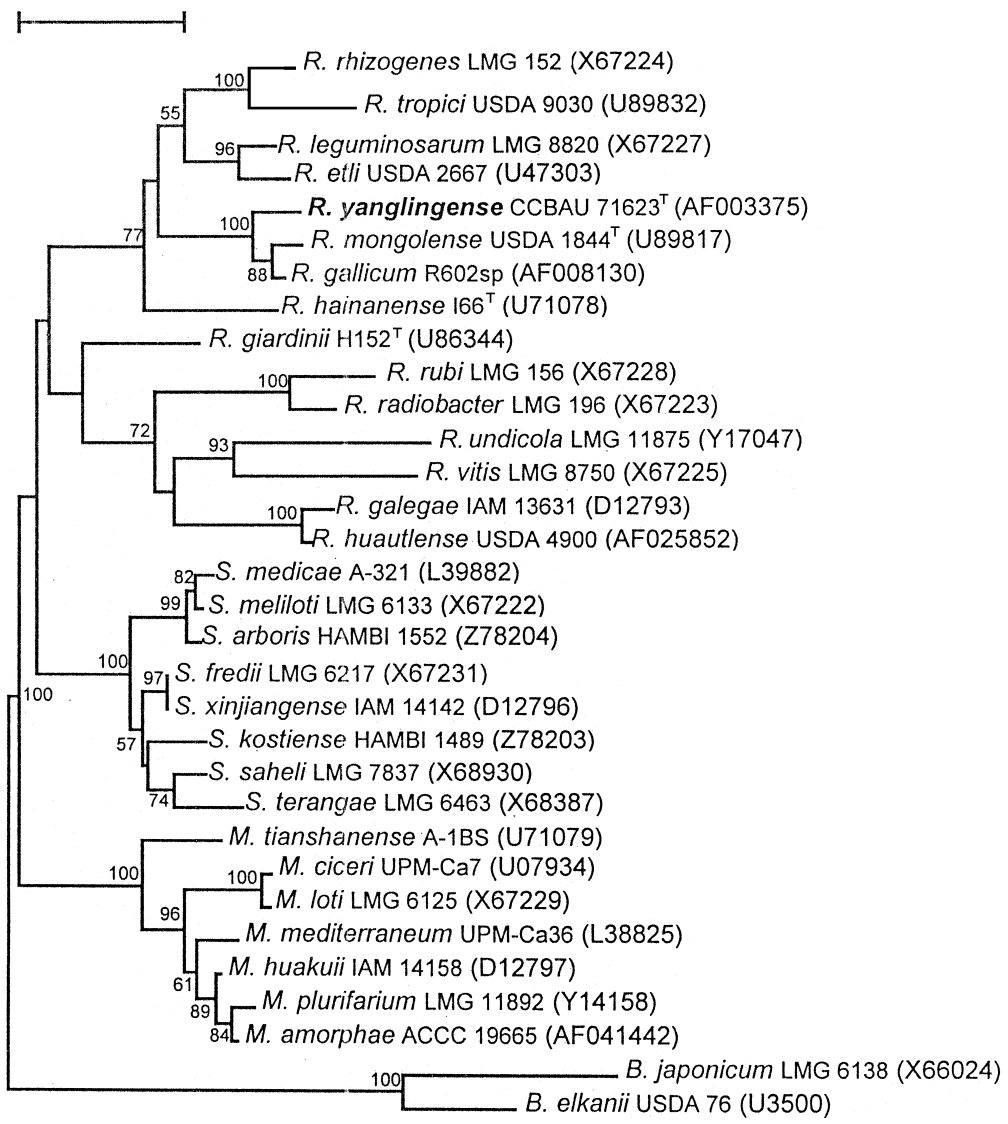

\begin{abstract}
Fig. 2. Phylogenetic tree constructed from a comparative analysis of 16S rRNA gene sequences showing the relationships among $R$. yanglingense and other species within the genera Bradyrhizobium, Mesorhizobium, Rhizobium and Sinorhizobium. The GenBank accession numbers of the sequences are given in parentheses. Sequences were aligned using the RDP (Ribosomal Database Project) program (Maidak et al., 1999). The Jukes-Cantor distance (Jukes \& Cantor, 1969), bootstrap (Felsenstein, 1985) and neighbour-joining method (Saitou \& Nei, 1987) were used to construct this phylogenetic tree using the TREECON package (van de Peer \& De Wachter, 1994). Bootstrap values greater than $50 \%$ are indicated at the branch points. The scale bar shows $3 \%$ nucleotide substitutions.
\end{abstract}

cluster 9 could nodulate Galega orientalis or Leucaena leucocephala. Strain CCBAU $71623^{\mathrm{T}}$ also nodulated Glycyrrhiza pallidiflora and Phaseolus vulgaris, but the nodules on Phaseolus vulgaris formed by this strain were inefficient and decayed very soon since most of the mature nodules were white or green.

\section{DISCUSSION}

In a previous numerical taxonomic study, nine rhizobial isolates from Amphicarpaea trisperma, Coronilla varia and Gueldenstaedtia multiflora formed a unique cluster, cluster 9 . Three representative isolates of this cluster had identical PCR-based 16S rRNA gene RFLP patterns, which were closely related to those of $R$. mongolense and of Rhizobium gallicum. These close relationships were also confirmed by the high similarities of partial 16S rRNA gene sequences. DNA homologies greater than $70 \%$ were obtained among the cluster 9 strains, but the relationships within this cluster and with the defined species were not completely described in the previous work (Tan et al., 1999).

In the present research, three new isolates were included and were identified as members of cluster 9 by analysis based on protein SDS-PAGE (Fig. 1) and DNA-DNA hybridization. The results of protein SDS-PAGE (Fig. 1), DNA relatedness and numerical taxonomy (Tan et al., 1999) indicated that the fast- growing, acid-producing rhizobial isolates from Amphicarpaea trisperma, Coronilla varia and Gueldenstaedtia multiflora were a single group different from all the defined species. Comparative analysis of $16 \mathrm{~S}$ rRNA sequences (Fig. 2) showed that this group was a member of the genus Rhizobium, and that it was closely related to $R$. gallicum and $R$. mongolense (> 99\% 16S rRNA gene sequence similarity). However, the DNADNA homologies among the isolates of cluster 9 and type strains of $R$. gallicum and $R$. mongolense were lower than $42 \cdot 4 \%$.

In addition, distinctive features for cluster 9 were described in our previous report (Tan et al., 1999) and other publications (Amarger et al., 1997; van Berkum et al., 1998; Wang et al., 1998). PCR-based RFLP of $16 \mathrm{~S}$ rRNA genes could be a useful molecular tool to differentiate cluster 9 from other defined species. Utilization of L-tryptophan as sole nitrogen source, and resistance to $5 \mu \mathrm{g}$ streptomycin $\mathrm{ml}^{-1}$ and to $1.0 \%(\mathrm{w} / \mathrm{v}) \mathrm{NaCl}$ could differentiate cluster 9 from $R$. gallicum, one of the most related species. Resistance to $5 \mu \mathrm{g}$ streptomycin $\mathrm{ml}^{-1}$ and to $1 \cdot 0 \% \mathrm{NaCl}$ were also features which distinguished cluster 9 from $R$. mongolense. R. gallicum and R. mongolense also formed effective nodules on common bean plants, on which cluster 9 strains formed ineffective nodules.

Based upon the polyphasic taxonomy performed in this research and in the previous work (Tan et al., 1999) and upon the current criteria to describe new 
rhizobial taxa (Graham et al., 1991), we propose cluster 9 as a new species, Rhizobium yanglingense.

\section{Description of Rhizobium yanglingense sp. nov.}

Rhizobium yanglingense (yang.ling.en'se N.L. adj. Yangling a town in Shiaanxi province of China, where the majority of strains within this species were isolated).

Aerobic, Gram-negative, non-spore-forming rods that are $0.5-1.0 \mu \mathrm{m}$ wide by $2.0-3.5 \mu \mathrm{m}$ long. Motile by means of a single polar flagellum. Colonies on YMA are semi-translucent, opalescent and usually $2 \cdot 0$ $3.0 \mathrm{~mm}$ in diameter after $3 \mathrm{~d}$ incubation at $28^{\circ} \mathrm{C}$. Optimum temperature $25-30^{\circ} \mathrm{C}$, and can grow at $37^{\circ} \mathrm{C}$ but not at 10 or $40^{\circ} \mathrm{C}$. Optimum pH $6-8$ and can grow at $\mathrm{pH} 5-9$, but not at $\mathrm{pH} 4$ or 10 . Generation time is $2 \cdot 8-3 \cdot 2 \mathrm{~h}$ in PY broth (Tan et al., 1999), as determined by the spectrophotometric method. Strains produce a lot of polysaccharide and acid on YMA medium. They do not produce 3-ketolactose from lactose. Most strains do not grow in LB medium (Yanagi \& Yamasato, 1993), with the exception of CCBAU 71121 and CCBAU 71931. No strains grow in media containing formate, salicylate, D-glutamic acid, L-methionine, $\beta$-alanine or L-threonine as sole carbon source. All of them can use L-alanine, Lglutamic acid or L-proline as sole nitrogen source. All strains are sensitive to $300 \mu \mathrm{g} \mathrm{ml}^{-1}$ of doxycycline, gentamicin and neomycin, and to $0 \cdot 1 \%(\mathrm{w} / \mathrm{v})$ bromothymol blue and gentian violet, but are resistant to 5-100 $\mu \mathrm{g}$ bacitracin $\mathrm{ml}^{-1}$ and 5-50 $\mu \mathrm{g}$ erythromycin $\mathrm{ml}^{-1}$. Growth is inhibited by $5.0 \%(\mathrm{w} / \mathrm{v}) \mathrm{NaCl}$ on YMA. Representative isolates from different hosts in cluster 9 show different EcoRI or BamHI restriction patterns of $\operatorname{nod} D A B$ with 2-4 bands and a single nifH band (Tan et al., 1999). The $\mathrm{G}+\mathrm{C}$ content of the DNA is $59-63 \mathrm{~mol} \%\left(T_{\mathrm{m}}\right)$. The type strain is CCBAU $71623^{\mathrm{T}}\left(\mathrm{SH} 22623^{\mathrm{T}}\right)$. Its DNA $\mathrm{G}+\mathrm{C}$ content is $62 \mathrm{~mol} \%\left(T_{\mathrm{m}}\right)$. The strains have been deposited in the Cultural Collection of Beijing Agricultural University (CCBAU), China, and in the Culture Collection of Laboratorium voor Microbiologie, Universiteit Gent (LMG), Belgium.

\section{ACKNOWLEDGEMENTS}

This research was supported financially by grant no. 39730010 from the National Natural Science Foundation of China.

\section{REFERENCES}

Amarger, N., Marcheret, V. \& Laguerre, G. (1997). Rhizobium gallicum sp. nov. and Rhizobium giardinii sp. nov. from Phaseolus vulgaris nodules. Int J Syst Bacteriol 47, 996-1006.

van Berkum, P. \& Eardly, B. D. (1998). Molecular evolutionary systematics of the Rhizobiaceae. In The RhizobiaceaeMolecular Biology of Model Plant-Associated Bacteria, pp. 1-24. Edited by H. P. Spaink, A. Kondorosi \& P. J. Hooykaas. Dordrecht/Boston/London: Kluwer Academic Publishers. van Berkum, P., Beyene, D., Bao, G. P., Campell, A. \& Eardly, B. D. (1998). Rhizobium mongolense sp. nov. is one of three rhizobial genotypes identified which nodulate and form nitrogen-fixing symbioses with Medicago ruthenica [(L.) Ledebour]. Int J Syst Bacteriol 48, 13-22.

Barrera, L. L., Trujillo, M. E., Goodfellow, M., García, F. J., Hernández-Lucas, I., Dávila, G., van Berkum, P. \& MartínezRomero, E. (1997). Biodiversity of bradyrhizobia nodulating Lupinus spp. Int J Syst Bacteriol 47, 1086-1091.

Chen, W. X., Wang, E. T., Wang, S. Y., Li, Y. B., Chen, X. Q. \& Li, Y. (1995). Characteristics of Rhizobium tianshanense sp. nov., a moderately and slowly growing root nodule bacterium isolated from an arid-saline environment in Xinjiang, People's Republic of China. Int J Syst Bacteriol 45, 153-159.

Chen, W. X., Tan, Z. Y., Gao, J. L., Li, Y., Sui, X. H. \& Wang, E. T. (1997). Rhizobium hainanense sp. nov., isolated from tropical legumes. Int J Syst Bacteriol 47, 870-873.

De Ley, J. (1970). Re-examination of the association between melting point, buoyant density, and chemical base composition of DNA. J Bacteriol 101, 738-754.

De Ley, J., Cattoir, H. \& Reynaeerts, A. (1970). The quantitative measurement of DNA hybridization from renaturation rates. Eur J Biochem 12, 133-142.

Dupuy, N., Willems, A., Pot, B. \& 7 other authors (1994). Phenotypic and genotypic characterization of bradyrhizobia nodulating the leguminous tree Acacia albida. Int $J$ Syst Bacteriol 44, 461-473.

Felsenstein, J. (1985). Confidence limits on phylogenies: an approach using the bootstrap. Evolution 39, 783-791.

Graham, P. H., Sadowsky, M. J. \& Keyser, H. H. (1991). Proposed minimal standards for the description of new genera and species of root- and stem-nodulation bacteria. Int $J$ Syst Bacteriol 41, 582-587.

Hurek, T., Wagner, B. \& Reinhold-Hurek, B. (1997). Identification of $\mathrm{N}_{2}$-fixing plant- and fungus-associated Azoarcus species by PCR-based genomic fingerprints. Appl Environ Microbiology 63, 4331-4339.

Jukes, T. H. \& Cantor, C. R. (1969). Evolution of protein molecules. In Mammalian Protein Metabolism, vol. 3, pp. 21-132. Edited by H. N. Munro. New York: Academic Press.

Kiredjan, M. B., Holmes, B., Kersters, K., Guilvout, I. \& De Ley, J. (1986). Aleuligenes piechaudii, a new species from human clinical specimens and the environment. Int $J$ Syst Bacteriol 36, 286-287.

Laemmli, U. K. (1970). Cleavage of structural proteins during the assembly of the head of bacteriophage T4. Nature 227, 680-685.

Lafay, B. \& Burdon, J. (1998). Molecular diversity of rhizobia occurring on native shrubby legumes in Southeastern Australia. Appl Environ Microbiol 64, 3989-3997.

de Lajudie, P., Laurent-Fulele, E., Willems, A., Torck, U., Coopman, R., Collins, M. D., Kersters, K., Dreyfus, B. \& Gillis, M. (1998a). Allorhizobium undicola gen. nov., nitrogen-fixing bacteria that efficiently nodulate Neptunia natans in Senegal. Int J Syst Bacteriol 48, 1277-1290.

de Lajudie, P., Willems, A., Nick, G. \& 9 other authors (1998b). Characterization of tropical tree rhizobia and description of Mesorhizobium plurifarium sp. nov. Int J Syst Bacteriol 48, 369-382.

Lane, D. J. (1991). 16S/23S RNA sequencing. In Nucleic Acid Techniques in Bacterial Systematics, pp. 115-176. Edited by E. Stackebrandt \& M. Goodfellow. Chichester: Wiley.

Maidak, B. L., Cole, J. R., Parker, C. T. \& 11 other authors (1999). 
A new version of the RDP (Ribosomal Database Project). Nucleic Acids Res 27, 171-173.

Marmur, J. (1961). A procedure for the isolation of DNA from microorganisms. J Mol Biol 3, 208-218.

Nick, G., de Lajudie, P., Eardly, B. D., Suomalainen, S., Paulin, L., Zhang, X., Gillis, M. \& Lindström, K. (1999). Sinorhizobium arboris sp. nov. and Sinorhizobium kostiense sp. nov., isolated from leguminous trees in Sudan and Kenya. Int J Syst Bacteriol 49, 1359-1368.

van de Peer, Y. \& De Wachter, R. (1994). TREECON for Windows: a software package for the construction and drawing of evolutionary trees for the Microsoft Windows environment. Comput Appl Biosci 10, 569-570.

Reinhold-Hurek, B., Hurek, T., Claeyssens, M. \& Van Montagu, M. (1993a). Cloning, expression in Escherichia coli, and characterization of cellulolytic enzymes of Azoarcus sp., a root-invading diazotroph. J Bacteriol 175, 7056-7065.

Reinhold-Hurek, B., Hurek, T., Gillis, M., Hoste, B., Vancanneyt, M., Kersters, K. \& De Ley, J. (1993b). Azoarcus gen. nov., nitrogen-fixing proteobacteria associated with roots of Kallar grass (Leptochloa fusca (L.) Kunth), and description of two species, Azoarcus indigens sp. nov. and Azoarcus communis sp. nov. Int J Syst Bacteriol 43, 574-584.

Saitou, N. \& Nei, M. (1987). The neighbor-joining method: a new method for constructing phylogenetic trees. Mol Biol Evol 4, 406-425.

Schagger, H. \& von Jagow, G. (1987). Tricine-sodium dodecyl sulfate-polyarylamide gel electrophoresis for the separation of proteins in the range from 1 to $100 \mathrm{kDa}$. Anal Biochem 166, $368-379$

Sneath, P. H. A. \& Sokal, R. R. (1973). Numerical Taxonomy. San Francisco: Freeman.
Tan, Z. Y., Xu, X. D., Wang, E. T., Gao, J. L., Martinez-Romero, E. \& Chen, W. X. (1997). Phylogenetic and genetic relationships of Mesorhizobium tianshanense and related rhizobia. Int J Syst Bacteriol 47, 874-879.

Tan, Z. Y., Wang, E. T., Peng, G. X., Zhu, M. E., Martinez-Romero, E. \& Chen, W. X. (1999). Characterization of bacteria isolated from wild legumes in the north-western regions of China. Int $J$ Syst Bacteriol 49, 1457-1469.

Vincent, J. M. (1970). A Manual for the Practical Study of the Root-nodule Bacteria. IBP Handbook 15. Oxford: Blackwell Scientific Publications.

Wang, E. T., van Berkum, P., Beyene, D., Sui, X. H., Dorado, O., Chen, W. X. \& Martínez-Romero, E. (1998). Rhizobium huautlense sp. nov., a symbiont of Sesbania herbacea that has a close phylogenetic relationship with Rhizobium galegae. Int J Syst Bacteriol 48, 687-699.

Wang, E. T., van Berkum, P., Sui, X. H., Beyene, D., Chen, W. X. \& Martínez-Romero, E. (1999a). Diversity of rhizobia associated with Amorpha fruticosa isolated from Chinese soils and description of Mesorhizobium amorphae sp. nov. Int J Syst Bacteriol 49, 51-65.

Wang, E. T., Martínez-Romero, J. \& Martínez-Romero, E. (1999b). Genetic diversity of rhizobia from Leucaena leucocephala nodules in Mexican soils. Mol Ecol 8, 711-724.

Wang, E. T. \& Martínez-Romero, E. (2000). Phylogeny of rootand stem-nodule bacteria associated with legumes. In Prokaryotic Nitrogen Fixation: A Model System for Analysis of a Biological Process, pp. 175-186. Edited by E. W. Triplett. Wymondham: Horizon Scientific Press.

Yanagi, M. \& Yamasato, K. (1993). Phylogenetic analysis of the family Rhizobiaceae and related bacteria by sequencing of $16 \mathrm{~S}$ rRNA gene using PCR and DNA sequencer. FEMS Microbiol Lett 107, 115-120. 